\title{
Do the Stories Help to Develop Communication Skills to the Students at School Level?
}

\author{
K. Gayithri Devi \\ Ph. D. scholar \\ Sri Padmavathi Mahila Visva Vidyalayam, Tirupathi. \\ “Communication is the lifeline of any relationship. When you stop communicating, you'll start losing your valuable \\ relationships."
}

\begin{abstract}
Communication involves freedom and unpredictability. In the so called "conversation practice", the students utter pre-written dialogue. There is no freedom, no choice and no unpredictability. Traditional teachers never gave them a chance and deprive the learners of freedom by giving them the correct response or interpretations. They avoid all vocabulary and structural items that are not prescribed. They will explain all new ideas and concepts in advance, leaving nothing unpredictable or undecided. Thus the learner fails to get a chance to manage himself/herself.
\end{abstract}

Now a days, this communicative skills are widely adopted in many parts of the world to teach the second and foreign language.

The English as a foreign and second language our teachers have felt that the ultimate aim of language forms are taught to the pupils with a belief that their knowledge would lead to the use of those forms in communication. But their transfer from form to use is not taking place in the majority of cases. Therefore, there is a growing feeling that teaching should be communicative centered based on activities.

Keywords:- Communication, unpredictability, pre-written, interpretation, Centered.

\section{INTRODUCTION}

Everyone loves to listen to stories. Stories keep children engaged and let them feel that they are also participating in the process of language learning. There are a part and parcel of one's life. Listening to stories has always been a pleasurable experience. They trigger the learner's imagination and sustain their level of interest with an opportunity. Thus language learning becomes effortless.

Stories are effective in enhancing communicative skills. Activities such as learning how to tell a story by writing it down, talking about it, and learning to actively listen to someone else's story teach important language skills in meaningful contexts. The more teachers know about stories the better they will be able to teach and model for their students.
> What are the benefits and challenges of using communicative activities?

- More exposure to target language.

- Fun and interesting for learners.

- Avoid stage fear.

- Help the students to get confidence to speak the language.

- These activities help to overcome the shyness and fear among the students.

$>$ Objectives

After reading this topic you would be able to,

- Choose such language activities which would bring in more communication among the students.

- Plan suitably and lessen the teacher talk

- Make our class more interesting and communicative, filled with activities.

Tasks for Developing Communication Skills.

Communication skills:

- Individual

- Pair and Group work

A. Individual:

There are many individual activities that can develop communication skills among the students through stories.

The following tasks can be made use of:

\section{$>$ Description:}

The students are given some characters and ask the students to describe the character that is involved in the story Ex: Aladdin, Sorcerer, Genie etc.

\section{Narration of story:}

This develops the student's expressional ability and enables them to articulate their experience. It develops lively imagination. The students may be first made to listen to story from the teacher or through voice recorder and made them to memorize that and later may be asked to narrate it.

\section{Picture Reading:}

Before saying a story by the teacher, he/she supplies the hand out, a picture of "Aladdin and the Magic Lamp" and asks the student to look at the picture and name every 
character of the picture in addition to that the teacher can ask the student to guess the story. Through the picture children can learn many words. This activity is designed to enable them learn words.

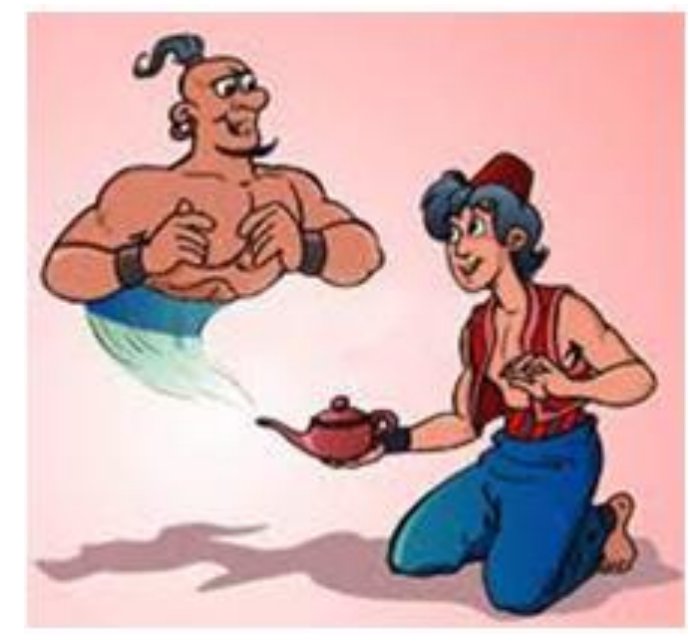

Fig 1

Express ideas in simple sentences:

Here the student should use simple sentences to express his/her idea according to the story.

\section{Example:}

- The cave is too small to enter.

- The lamp is too old to see.

- The Genie is too big to look.

\section{$>$ Narrating story through gestures:}

Gestures play a significant role in the communication between the students. To communicate something that the speech is not saying or to communicate solely through gestures without the accompaniment of speech. Here by understanding the story when one of the students narrate the story through gestures and the other students say the sentences based on the story. This encourages the child who told the story to help the other children act the story out in the way the child envisioned it.

\section{Identify vocabulary and usage:}

In this activity, according to story the teacher supplies some words which are difficult to understand,such words written on flash cards. The student has to give his own sentence by using these words.

\section{Example:}

\section{- Summoned}

$\checkmark$ The king Sultan summoned Aladdin.

- Succeed

$\checkmark$ Aladdin succeeded on the wizard at last.

- Disguise

$\checkmark$ The wizard disguised as a peddler.

\section{B. Pair and Group Work:}

Pair work and group work formsare important part of any communicative activity. These allow students to mix with everyone in the group. The conversations or dialogues practiced in pairs by the students in a class room is known as pair work. When this activity is going on, the teacher goes round the class and guides the students to do their activity in a proper way.

The pair and group work activities through stories develop communicative competence among the pupils. These are:

\section{Asking Simple Questions:}

Here the students will have two sets of hand out, in these one cardhas questions, in another card answers. In pairs one learner asks questions about story that the second learner has to answer by watching his hand out.

\section{Example:}

Pupil 1: Where did the story take place?

Pupil 2: In Arabia.

Pupil 1: How many Genies are there?

Pupil 2: Two.

1. Where did the story take place?

2. How many Genies are there?

3. Who is Halima?

4. "Now you will be my wife "who shouted?

5. Who offered to pay Aladdin a silver coin?

- Sultan's Daughter

- Two

- In Arabia

- The Sorceror

\section{Finding Someone Who / Something What?}

The teacher distributes a card board to a student which has hints or clues. That student has to enquire with the other pair by asking who is this? / What is this?

\section{Hints / Clues}

- The opening is too small to enter.

- If you rub, you can get whatever you want.

- He is very happy to see rightful owner againWho/What is that?

- He belongs to Arabia and very active.

- There is a mysterious stranger and offered to pay silver coin.

Answers: Cave, Lamp, Genie, Aladdin, Sorcerer

\section{Observing the picture:}

In this activity the first student is given a picture of "Aladdin and the Magic Lamp". The other has to answer the questions by watching the picture. 


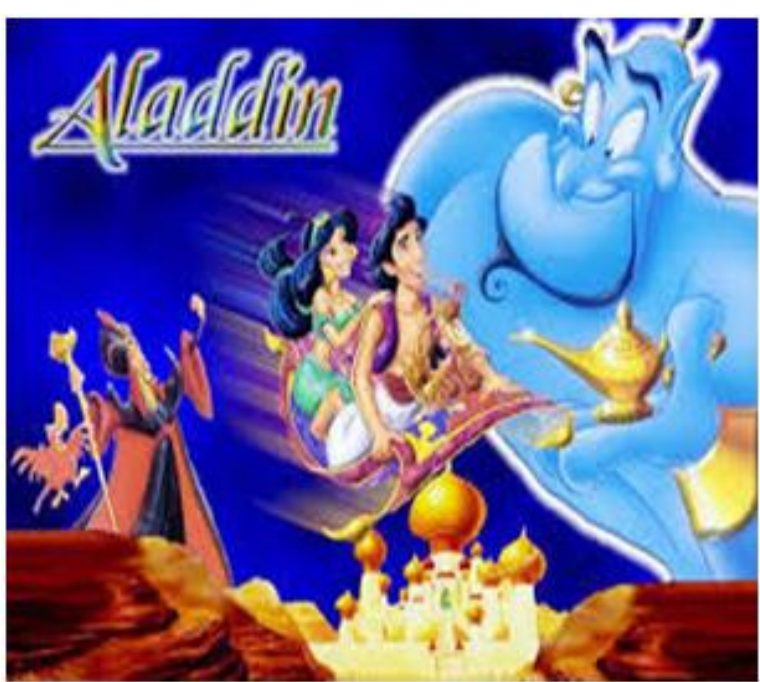

Fig 2

Ex. Pupil 1: Are they flying?

Pupil 2: Yes, they are.

Pupil 1: Is Genie small?

Pupil 2: No, It is not.

Pupil 1: Was there a Sorcerer?

Pupil 2: Yes, there was.

Pupil 1: Is there a sea?

Pupil 2: No, there is not.

Pupil 1: Is there a palace?

Pupil 2: Yes, there is.

\section{$>$ By performing actions:}

There are some words which actions can be performed. For example: pushed,fell,slipped,rub,hungry,marry,magical,laugh etc., These words should be performed by actions, the other should identify the words. Childrenlove to learn words through this activity.

\section{Group Work:}

This can be done through activities. The students will be divided into 4 or 5 groups and given tasks.

To develop listening and speaking the basic skills of oral communication, the students may be divided into different groups and in each group they discuss the tasks given to them and come out with a solution. They have to agree with each other after certain amount of discussion. These activities are helpful in group work for developing free and spontaneous use of oral communication.

\section{$>$ Relaying Instructions:}

In this type of activity, a group of students has the necessary information for the performance of a task. They have to relay those instructions and the other group has to perform the same task.
Example: Reaching the cave safely.

A small group of students are given the following instructions by another group of students.

- Wear a helmet and gloves.

- Hang the thread and hold your hand tightly.

- Slide slowly.

- Watch your step, don't run or jump on or off anything.

- Drop hands and get down slowly.

\section{$>$ Reaching Consensus:}

The students are told that they are going to cave. Then the teacher will ask them to write down any ten articles they would like to bring to the cave.

First, the students will write down the articles individually. Then they will form pairs and discuss with each other and come out with another list. Two or three pairs again form into one group and final list of ten items can be formed and thus they reach consensus.

Example:

Group 1: Gloves, rope, shoes, helmet, knee pads, torch light, bag, pen.

Group 2:Water bottle,knife, route map, first aid kit, whistle, towel, compass, watch.

\section{Questioning answers spontaneously:}

Here the teacher makes the students in to three or four groups and allot the paragraphs of story. Then the teacher reads the story slowly that means she/he stops at each and every sentences. Whenever she stops reading, at that time the students have to listen and frame the questions for each and every sentence.

\section{Example:}

Once upon a time in Arabia, there lived a poor widow who had a son named Aladdin. One day, they met a mysterious stranger who offered to pay Aladdin a silver coin in return for doing a simple task:

- Who lived in Arabia?

- What was offered by a sorcerer?

- How many characters are mentioned here?

By listening these sentences, they frame the questions spontaneously. This will be given to every group. This activity is helpful to students to learn how to frame questions.

\section{Guess the Emotion:}

It is simple, effective, easy, helpful and enjoyable for students.

- Divide the group into two teams.

- Give each item a set of cards with an emotion on it.

- Have a participant from Team 'A' act out the emotion on the card until his or her team guesses correctly. Switch and have Team ' $\mathrm{B}$ ' act out their card. 


\begin{tabular}{|c|c|}
\hline Team-A-Card Team-B-Card & \\
\hline $\begin{array}{l}\text { - } \quad \text { The opening the cave is too small to enter. } \\
\text { - } \quad \text { Give me the lamp. } \\
\text { - }\end{array}$ & $\begin{array}{l}\text { The cave was filled with treasures. } \\
\text { The wizard pushed Aladdin back into the } \\
\text { What is your wish? }\end{array}$ \\
\hline
\end{tabular}

The teacher has to assign short time limits such as one or two minutes for the group to guess.

\section{Structured Activity:}

Teacher makes the students a small group and asks to stand in a circle.

Each student has to ask the other....

Example 1:

My name is Aladdin. What is your name?

My name is Genie. What is your name?

My name is Halima. What is your name?

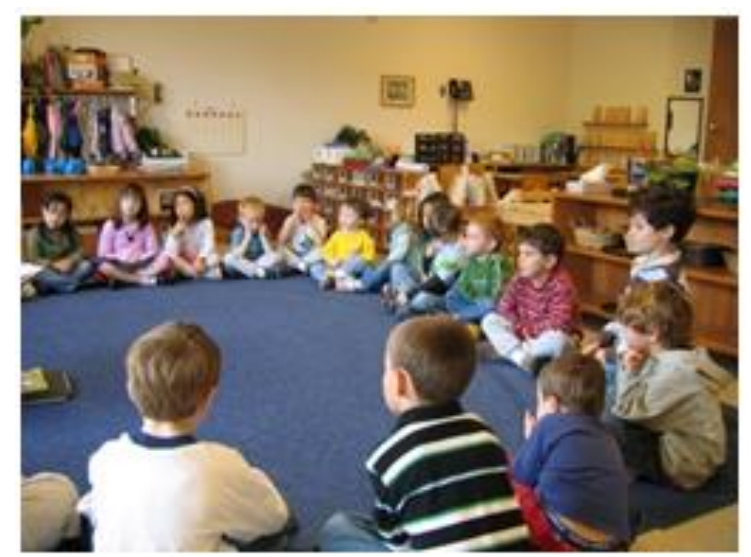

Fig 3

Example 2:

I have Silver Coin. What do you have?

I have Magic Lamp. What do you have?

I have Ring. What do you have?

I have Treasures. What do you have?

Example 3:

I want to go Home. Where do you want to go?

I want to go to Cave. Where do you want to go?

I want to go to Sultan's Kingdom. Where do you want to go?

I want to go to Arabia. Where do you want to go?

\section{CONCLUSION}

This should be followed by practice in which the studentsworkout a series of activities. This ensures learning and transfer of learning from short- term to long-term memory. The teacher, here, should give an informal feedback; so that, the acquisition of skills will become perfect. These activities develop confidence in them and acquire the skills interestingly, spontaneously,unknowingly and involuntarily.

\section{REFERENCES}

[1]. Joiner, E. (1977).Communicative Activities for Beginning Language Students. EnglishTeaching Forum, April, 15, Pp. 8-9.

[2]. Michi Farida Abdul Halim, Nor Hasni Mokhtar and Sharifah Zarina Syed Kamarulzaman. The Effectiveness Storytelling in Enhancing Communicative Skills. University KebangsaanMalasia, Malasia, 2011.

[3]. Nunan,D.(1988).Designing Communicative Tasks for the Language Class room. Cambridge: Cambridge University Press.

[4]. Tell a Tale Language Learning Channels. Regional Institute of English, South India.

[5]. Vasundhara, D and Katyayani, R. K. Methodology of Teaching English. Hyderabad: Telugu Academy, 2008.

[6]. Vijayakumar, Annie(2004).Methods of Teaching English.Guntur ;New Era publications.

[7]. Widdowson, H.G .Teaching Language as Communication. Oxford: Oxford university Press, 1978. 